\title{
ON THE EXISTENTIAL SECURITY IN VIEW OF THE MODERN PHILOSOPHY CONCEPTIONS ON TRANSCIENCE
}

\author{
Marek ADAMKIEWICZ
}

Wojskowa Akademia Techniczna

Arnold WARCHAt

Wojskowa Akademia Techniczna

\begin{abstract}
The authors continue their discussion on transience as an existential security problem in philosophy, understood differently in particular historical periods. The third article on a subject presents modern philosophical positions on the temporality of man, with transience continually understood as the criterion of existential danger. The end of existence is treated as a source of anxiety, but this time free from earlier (i.e. medieval) inspirations based on expiation and hope for salvation, considered now, however, as a barrier to the unquestionable life rewards within the materialistically imagined world. Modern life concepts that were released, not without difficulty, from religious intellectual domination, foretold visions of not afterlife but temporal existence. Hence, the existential security born of this was sometimes distant from theology, despite the fact that it did not question the two-dimensional interpretation of being, and advocated the concept of life explained by the process of scientific (and philosophical) inquiries, suggested by studies in mechanics or medicine. Despite the significance of intellectual change that followed the separation of philosophy from theology (XVI century), and later the science from philosophy (XVI century), positions related to transience (death) were rather limited in number compared to, for example, the ancient period, and quite trivially commenting on this, after all, the most important life episode, in view of the life purposefulness, as was visible in the medieval period. Nevertheless, the weight of existential views is heavy in modern times, and even fascinating, as was the case, for example, with the thought of Soren Kirkegaard. Considering this circumstance of conscious utterance of fear of death, and the attendance to the material aspects of life, presents rather meaningful issues in reference to dying, as the authors sketch out. Because of those, the connection between perceptible existential appearance of life, and its security context, will be visible in the emancipating European modern philosophy. Keywords: individual security, philosophy, modernity, threat, transience.
\end{abstract}

Amongst the intellectual riches of the Renaissance (XV-XVI century), one of the most important was that of the reorientation of philosophical interests. The former concentration on the study of transcendentals, underlined by the glorious importance of the famous memento mori (remember that you will die) perpetuated in scholastic thought, was contrasted with the earthly joy of life, modeled on the postulates of classical philosophy. ${ }^{1}$ It was understood that in new times the goal was

1 See for example M. Walicki, Studia renesansowe, Ossolineum, Wrocław 1964; or E. Garin, Filozofia Odrodzenia we Włoszech, PIW, Warszawa 1969; This and other bibliographical references are based on Polish language books. 
to educate people open to temporality, rejecting dogmatic and formal models of thinking from the previous epoch. The source of medieval intellectual „barbarism” was found in the Aristotelian logic. His studies on nature, however, were considered with esteem. It was also believed that acceptance of Plato (especially because of the "beauty and clarity" of his dialogues), the atomism of Democritus, the Epicurean

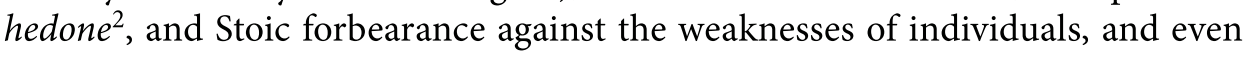
Cerenaic rationalism (pleasure considered as the ludic purpose of life), may bring on conditions for a happier existence, not only carnal, but also spiritual (because of the openness to the real external world). ${ }^{3}$

According to the views accepted in history of philosophy, the Renaissance thought was guided by two assumptions. First, it wanted to overthrow and eradicate scholasticism, and second, it wanted to build a new worldview on its ruins. To attain these goals, the outmost importance was complete independence of the dogmatic and religious matters, or at least, freedom of thought and right to seek independent assessment of reality, regardless of the judgments of church authorities about it. The admiration for classical philosophy was based especially on its "free-thinking" character. According to contemporary beliefs of that period, ancient Greece and Rome created the paradigm. It was the intellectual freedom from coercion by people of power and influence. Therefore, it was suspected that meditation and research on natural aspects of life (as exemplified in the works of L. da Vinci, M. Kopernik, J. Kepler, G. Galileo, T. Paracelsus, G. Bruno), released from the medieval theology moral and social thought (as presented by the views of M. Machiavelli, T. Morus, T. Campanella, H. de Groot), and new religious thought (expressed in the contestations of M. Luther, U. Zwingli, J. Boehme and Erasmus of Rotterdam), will give rise to the proper liberation of people from the domination of the old ideology ${ }^{4}$. Within these changes, the problem of death has also lost its paramount importance. More attention has been paid to matters related to life itself, than to the issue of passing away, which, as a testimony to interests of the previous era, had to remain on the sidelines of reflection on man and his surroundings. After all, a change in the worldview orientation did not mean then, or later, the total abandonment of thinking about death and the existential blasphemy of individual life. Although the problem itself lost its former particular importance, this did not diminish its continuous general importance and meaningfulness.

People were still deliberating about death. Fears and questions mounting on this subject did not lose their relevance, although the philosophers basically fled the issue.

2 Hedone (gr.) - the goddess of pleasure in Greek mythology; in the Epicurean philosophy hedone implied the pleasure arising from the virtuous activities.

See J. Burckhardt, Kultura Odrodzenia we Włoszech, PIW, Warszawa 1991.

In J. Legowicz, Zarys historii filozofii. Elementy doksografii, Wiedza Powszechna, Warszawa 1983, pp. $270-284$. 
At that time it was considered - and it turned out to be a strategic program - that death, as a law of nature, is beyond the reach of human perception, and thus, it can not be the subject of any (especially the transcendental) speculation. Later, thanks to Descartes (XVII century), the ground for modern perception of knowledge was prepared. Hence, the modern philosophy was born. It rested on the assumption that the "non-world" is the subject of theology, and what is perceptible and verifiable is subjected to rationalism. Two centuries later, it was the positivism creating a worldview that gave only the perception of the "real objects" the rank of phenomena worthy of scientific considerations. Within this orientation, death has became just the empirically recorded end of being, subjected to human perceptiveness. On the moral plane, everything that was associated with its description was based on the observation of the impact of death on the quality of life, and thus simply associated with the impressions and impact of transience on human conduct. Lack of consent for the views held in the Middle Ages about the dual energy of man (body and soul) divided not only the intellectual tradition, but also the people themselves: into believers and atheists. At the same time, these divisions were not based only on the sympathies of religious persuasions, but mainly on the distrust for the potency of human knowledge. In other words, the mystery of the external world, and the bleakness of its full explanation by contemporary reason, became a turning point directing thinkers towards the reformulation of many issues, with some solutions found in an empirical research.

Therefore, in a longer run of this intellectual proposition leading to Modernity, in the second half of the XIX century, it was already accepted (in part because of August Comte positivism) that the description of facts and avoidance of metaphysic is the only proper way of approaching the explanation of reality. The positivistic philosophy influenced by the attitude of modern science, directed its interest towards the natural-social issues, and focused on the following problems in scientific research of: 1) only the real - not imaginary objects (things available to the mind); 2) reflections on useful and not barren topics (those that affect the improvement of life, and not just serving to satisfy the sense of curiosity); 3) problems allowing for the acquisition of certain knowledge, and, accordingly, avoiding the "shaky" subjects (that is, those that lead to "eternal disputes"; 4) strict issues that exclude vague contemplation; and finally 5) positive work, which is not limited to negative criticism of verifiable statements. ${ }^{5}$ In view of this perspective, the phenomenon of human death would only be considered in relation to its psychological and social effects, while the very problem of the continuity of existence, in a different - than an earthly - dimension, remained on the sidelines of philosophical reflections. Within this perspective it was rather preferred to return in ancient writings to those, connecting the thread of death to natural world and human temporality (as

5 In W. Tatarkiewicz, Historia filozofii, T. 3, wyd. VI, PWN, Warszawa 1968, p. 18. 
in Socratic philosophy, Aristotle's physics, Epicureism, Stoicism). And this seems to be characteristic of all philosophy encompassing modernity, from the period of Renaissance until the middle of the $\mathrm{XX}^{\text {th }}$ century.

The growing number of trends and positions in modern philosophy was not, however, indicative of any significant increased interest in problem of transience. The change in those interests became only apparent in the modern era (beginning with the 1970s), when the researches on death gained a new dimension. In the first accounts the inspirations were rather Platonic, and from such perspective seemed to defend the hypotheses of transcendental science of the Middle Ages. And these new interests seem to be closer to psychology (and even neurology, and physics) than to philosophy itself. ${ }^{6}$ This means that the question of death escapes epistemology or ontology, although it still remains the subject of moral philosophy, especially its new form: bioethics, and specifically of tanatology.

In modern times, the first reflections on death are found only in the works of Michel de Montaigne (XVI century). According to him, it is a phenomenon thoroughly piercing human fate. The awareness of its existence strengthens in situations of encounters with suffering and illness, that remind us about inevitability of the end. Healthy and young people take little time to consider the temporality of human fate, but in a moment of reverie they can hardly bear the thought of the arrival of death. The situation is different for sick people who weighed less on the "love of life", as the loss of the possibility of costing its charms favors the disappearance of horror due to passing away. "It gives me hope", wrote M. Montaigne, "that the more I move away from life, and approach death, the easier it will be for me to get used to this change. Just as in many circumstances, I confirm what Caesar says, that things seem to us often bigger from far away, than from up close, so I noticed that being healthy I was much more afraid of diseases, than when ill (...). I hope that the same will seem to me with death"?

Poor knowledge of sensations and states, that emanate from natural cause of human destiny promote the most common fear of death, with its imaginary face. And yet, someone who "processes" his own life through useful activity is free from the threat of death. Montaigne, after Epicurus, argued that fearing death was the result of life itself. This can be contemplated in human temporality, only here and now. Meanwhile, after death, when there is no more earthly existence, old

6 See for example A. Brodziak, Jesteś nieśmiertelny, Zakład Poligraficzno-Papierniczy, Bytom 1990, pp. 8-22, 28-31. Literature quoted by the authors - especially periodicals - shows a serious interest in the problem of the immortality of human existence on the part of representatives of basic sciences (naturalists, doctors, physicists). The Christian philosophy is represented here also by Polish thinkers: M. Heller, Kwantowa kosmologia i ostateczne rozumienie wszechświata, „problemy” 1989, nr 2, and: J. Życiński, Filozofia w nowej fizyce, "Problemy" 1989, nr 6.

7 M. de Montaigne, Próby, przekł. T. Żeleński (Boy), t. 1, PIW, Warszawa 1957, p. 154. 
values cease to count, and this already causes all desires and worries to pass away. ${ }^{8}$ Although, it is impossible to known when and where death will cross our path, we should expect it everywhere, but within the framework of intelligent reflection. And it is worth considering the blessing of contemplation about the triviality of human life, because of it. In reflections on the impermanence of existence, one can see freedom discovered because of death, or new sense of conscious existence, and the possibility of choosing ways leading to setting the proper goals of importance. Someone who has already acquired enough distance from it, that is "learned to die", has satisfactorily became free. Rejection of the fear of death, also implies freeing oneself from the various kinds of oppressing fears and own weaknesses. ${ }^{9}$

Francis Bacon (XVI / XVII century) also spoke on a subject with a similar tone as Montaigne. Additionally, he claimed that the usefulness of human life rules out any malicious transience. Those who are busy with their life, occupied by it, and, therefore, needed, have no need to discuss something that is natural and results from the order of things, thus being inevitable. Only a lazy man, or stupid, can be occupied by that, what does not depend on him anyway. And although it may seem that dying is unpleasant, it may not be much different from birth, the impressions of which are oblivious. It may also be that the iniquity of agony is equal to the annoyance of birth (or vice versa). Nobody who was born talks of birth, because remembering the act itself, and possible description, escapes our early memory. We perceive our own birth as a normal state of nature. Similarly, death is also a normal consequence of birth. Not the one, who has died, but only those who survive, remember occurrence of death. That is why the most important seems to be leading such an existence, that is intended to achieve high-value goals, realizing individual expectations, because based on the achievements, the human life is judged and remembered. "Whoever dies", wrote F. Bacon, "busy with serious affairs, is in a similar state, as the one who gets injured in a hot fight: he does not feel a wound at the moment of reception; Therefore, the mind focused on something positive turns off the thoughts on fear of suffering death" ${ }^{10}$

Blaise Pascal (XVII century) placed death among those phenomena, that awakes especially the sense of loneliness in most people. According to philosopher, the human subject "compared to infinity is a nobody, the middle between nothingness and everything". Therefore, as a being far-off from understanding the finality of existence, man is unable to comprehend either the ends of things, or their origins, for they remain for him "forever hidden in an impenetrable mystery." Man is equally incapable of seeing the nothingness from which he was torn away, as well as

8 Isn't this, that death - asks philosopher - touches much more cruelly the dying than dead? (...) If you fooly utilized your own life: you can leave it happy." (Op. cit., p. 158).

9 In Op. cit., p. 49.

10 F. Bacon, Eseje, PWN, Warszawa 1959, p. 9. 
the infinity into which he was plunged. ${ }^{11} \mathrm{He}$ noticed - emphasizing the fragility of human existence - that death itself is not able to change the directions of human's irrational behavior in life. The inevitability of its coming does not change the human attitude towards important things; it does not contribute to the fulfillment of tasks, masking the sense of short-term existence; and also does put any significance on the contemplations about the future (means its salvation). Therefore: "People - wrote B. Pascal - not being able to find a cure for death, misery, ignorance, decided to achieve happiness by not thinking about it". ${ }^{12}$

People behave and acts as if they had an indefinite time to live. Therefore, they are oblivious to the limitations and temporariness of one's own destiny. On the one hand, individuals are consumed "days and nights by rage and despair, because of a loss of a work status, or an imaginary insult of honor", and on the other, think without "anxiety and emotion", that everything will lose through death. ${ }^{13}$ And yet, the last act of being is dramatically overwhelming, regardless of everything that was achieved or desired in life. Even the most beautiful existence - joyous and rich - ends in a tragic finale: "clumping the earth on your head and here is the end forever". ${ }^{14}$ In spite of this, the world of human care does not include what is most important. People waste the precious time on games, and, more often, destroy the efforts of fellowmen, equally "miserable and powerless", in view of their likeness to each other (in the face of death). A man willingly ruins own life, spins unreal plans of a happy existence, in which delusions is preferred over the search for truth, and the sense of own existence. "We are looking for happiness - said Pascal - and we find only misery and death" ${ }^{15}$ Nonetheless, the hope of finding consolation in company of similar mortals, to commiserate with us, is rather tragically hopeless. Being happy because of similarity to others, does not change a fact that one dies in loneliness and fear. ${ }^{16}$

For Pascal, however, the awareness of transience as the cancelation of individual existence is what distinguishes humanity in the universe. "Man", said the scholar, "is only a reed, the most frail in nature, but a thinking-reed. It is not necessary for the entire universe to arm itself to defeat it: a drop of water is enough to kill a fog after all. But even if the universe crushes him, he is still nobler than the universe, because he knows he is dying, and knows of the advantage universe has over him. The universe, however, knows nothing about it". ${ }^{17}$ The only escape from the fear

1 All citations from: B. Pascal, Myśli, Instytut Wydawniczy Pax, Warszawa 1989, p. 63.

12 Ibidem, p. 125.

Ibidem, pp. 171-172.

4 Ibidem, p. 127.

15 Pascal elsewhere wrote: "I agree that somebody does not explore Copernicus's views, but (...) for all life, it is important to know whether the soul is mortal or immortal", op. cit., p. 178.

16 Ibidem, pp. 113, 178.

17 Ibidem, p. 140. 
of death is faith in Jesus Christ, who with his passion and courage endured the disgusting and terrifying dimension of death. In this act the Son of God gave it a different character: "charming, holy and joyful"; that's why he suffered and died, to sanctify human death and agony in life. Therefore, the Christ "[As] God, and as man, he was all that is great, and all that is wretched, to sanctify all things, with the exclusion of sin, and become a model for all kinds of [human] condition". ${ }^{18}$

The views of another great philosopher, Baruch Spinoza (XVII century), like Pascal's were also within the contemporary theistic trends of philosophical considerations of the times. The highest good, according to him, the knowledge of God, since it arouses love, and by transience leads to union with the Creator. Man's feelings and passions are the products of necessity (i.e. the laws of nature), although there is an inclination to freedom in his behavior. Human actions are also determined by the laws and relationships prevailing in the existing reality, but grow out of constructive nature of the subject. At the same time, some affects and actions were to be the result of reason, while others were evoked by the environment. Death was one of the necessary phenomena, and so it was the result of the same order in which a an was addicted to higher order drive, because of a natural (God's) determinants. For this reason, the disappearance of individual life should not be a source of vague contemplation, or cause of hostile feelings (e.g. fear). Just as the reasonableness of the existence of nature is not dispelled, one should not discuss the mysteries of being, since its manifestation is beyond the possibilities of human cognition. "Free man," wrote Spinoza, "does not occupy mind with death, and his wisdom is a reflection, not of death, but of life." ${ }^{19}$ Accordingly, transience, like everything we encounter in nature, should be understood and not condemned. Only this seems to be reasonable, because it is in accordance with existence. Whoever according to his nature is rooted in the laws of nature, is free.

This Spinoza's view, interestingly, was criticized by the existentialists, especially by Miguel de Unamuno (XX century), who considered the freedom interpreted in this sense to be tragic for human contemplation on sense of existence and transience. According to him, avoiding thinking about death may be a sing of freedom only for „dead man”, unconstrained by the „spring of life” and empty of love. Other

18 B. Pascal, Rozprawy i listy, Wydawnictwo Pax, Warszawa 1962, pp. 259-260. Also in B. Pascal, Myśli, op cit., pp. 383-385. Let us add that Pascal was a determined opponent of the imputation by the philosophy of "incentives" that urge man to reject the fear of death and care for salvation. For this reason, he made an extremely strict assessment of the views of death expressed by M. Montaigne. The background to the accusations was to be the "pagan beliefs" (Epicurism) of the latter, which led directly to giving the instructions "dying cowardly and comfortable" (in Myśli, op. cit., pp. 5758). Thus, Pascal's concept has been exposed in a clearly pessimistic sense of his statements about death.

19 B. Spinoza, Etyka w porządku geometrycznym dowiedziona, PWN, Warszawa 1954, p. 314. 
words, someone would be "a slave to own freedom", that he could not direct ${ }^{20}$. It is difficult, however, to agree with this view, because Spinoza's clear intention was to free man from unnecessary and sterile considerations such as the validity of death, or the meaningfulness of life from the point of view of human logic. Regardless of what would be said in this matter, death itself - as a natural phenomenon - remains outside the sphere of our decisions. And if so, a man can choose between two solutions: either to acknowledge its reality and inevitability, and in this respect to deal with things it has an impact on, or fruitlessly rebel against something that exceeds the possibilities of all contestation. Spinoza, not believing in the effectiveness of the struggles of human thought with passing away, chose the first way, giving it a healthy-sense dimension.

Another philosopher of the times, Françoise-Maria Arouet - called Voltaire (XVIII century) - also appreciated the rationalism in his views. Understanding the tragedy of death, urged a passive attitude towards it. Man as the only creation on earth is aware of his own fragility and temporariness of existence. This visualization saturated with sadness is inseparable from humanity only because it has been given the opportunity to think and, consequently, to consider the fate of one's own destiny. Death, therefore, as a natural phenomenon, appears in colloquial meaning as "a misfortune inevitably connected with the human trap", or evil that persecutes a human being forever. ${ }^{21}$ And this is not the only tragedy in human life. The ineffectiveness of human struggle with old age and death, as the common concerns of our lives, teaches that human effort should focus on this suffering (evil) that can be eradicated. That which is beyond the reach of human potency should not occupy us, for only matters subjected to man's power allow progress in dealing with all kinds of nuisances. Therefore, searching for the sense of existence, faced with the gloom of death (punishment for sins) perpetuated in religions, it is in life that people may find it, and maybe even joy. The best way is to overcome evil in interpersonal relations, especially since none of the former philosophical systems seeking good has become universally effective program. Although little can be done in the work of excluding evil itself, it must be constantly counteracted. Therefore, repairing existing wickedness is a suitable goal for human activity as well as reflection on their sources. It is therefore wise to lead such a life that at the moment of death could be considered fair. The easiest way to do this is by excluding everything an individual would not want from others. In this respect, the existence of evil and suffering, and vulnerability to these ailments of life should rather stimulate individual eagerness to abolish them, rather than limit the possibilities of struggling with the hardships of one's own life. However, at first we do not know the chances of effectiveness of

20 In M. de Unamuno, O poczuciu tragiczności życia wśród ludzi i wśród narodów, Wydawnictwo Literackie, Kraków-Wrocław 1984, p. 47.

21 In Wolter, O życiu, miłości i śmierci, PWN, Wrocław 1961, p. 31. 
such efforts, but in the perspective one can expect a just assessment of our actions. For only a sense of good and useful existence allows one to calmly think about death, and also to arouse the sorrow of the surroundings because of our departure. "When we come to the world we cry - wrote Voltaire - others laugh. By dying let us laugh, let others cry".22

According to Adam Smith (XVIII century) - father of political economy - death is a phenomenon of mental anguish, not because inevitable and widespread, but because the inevitable contact in life with dying or dead person acts on our senses. There are the circumstances accompanying death (fear of the unknown, pain, despair, helplessness, etc.) that force us to think of passing away as a cruel and incomprehensible act of life's judgment. Death of other people, by touching our consciousness stimulates egoistic thoughts about the sense of individual existence, especially because it is accompanied by the certainty of its own end. The considerations arising confront the experience of life, and the values recognized in it, with an unknown dimension, and therefore terrifying. We are unable to understand and acknowledge its necessity. We suspect, therefore, that the "future being" is to remain in nothingness; "Staying" in an environment devoid of sunlight and the impossibility of communing with others. Also the awareness of the loss of old meaning in the world of living people, erasing themselves from the feelings and memories of "dearest friends and relatives", as well as the inevitability of decomposing one's body, which was given so much attention during life, depressing and leading to fear for its own fate. ${ }^{23}$ We therefore feel empathy and compassion for the deceased, believing that even the greatest devotion on their part was nothing compared to the "terrible disaster", that has happened to them. Offering the deceased empathy seems to be justified especially when they are in danger of oblivion. Therefore, feeling their misfortune, we indirectly think about ourselves. After all, we do not want this fate that will lead us into the abyss of human oblivion. Besides the fact that our sympathy is not able to bring consolation to the dead, it seems to be an additional moment in our defeat. Facing death usually alleviates all the other annoyances encountered in life, and eroded by feelings of rejection, love, or regrets of relatives, underlines only the tragedy and certainty of the unfortunate destiny, which is to be, after all, a part of our participation in it. Therefore, this image of the "terrible and infinite sadness" of dying people, flows not from the real impressions of these people, but from the fact that we put ourselves in their situation. "This very illusion of imagination," wrote A. Smith, "makes predicting our own death so terrifying for us, and that the images of these circumstances, which will undoubtedly be unpleasant for us after death, make us unhappy during our lives". ${ }^{24}$

22 Ibidem, p. 30.

23 Por. A. Smith, Teoria uczuć moralnych, PWN, Warszawa 1989, p. 11.

24 Ibidem, p. 12. 
Johann Gottlieb Fichte (XVIII/XIX century) considered death equal to birth. Both acts of nature are the same, for death is the "act" of the nascent new life, and its beginning is the continuity of the disappearance of some existence. In dying, according to this philosopher, the elevation of life is manifested, as in nature there is no "killing principle". After all, nature is a permanent existence; it kills not death, but "a lively life" which is hidden in passing entities heading towards their end, just as nature tends to rebirth. It is in life that the quest for the death of every creature begins and develops, which was created somewhere, and at some point. So death and birth are those moments that manifest in the universal will of existence, and being in the time set by nature. "And how could my life be my death? - asked the thinker - since I am not only presenting and recreating my life, but I have life in myself, the only true and important life? It is almost unthinkable that nature should kill life that does not come from it, since I do not live because of nature, but nature lives for me (...) Just because it kills me, it must awaken me to life. My present life can only disappear in my higher life, which develops in it, and what mortal man calls death, is a visible manifestation of the second life". 25 The ubiquitous testimony of death in nature is a sign of existence that exceeds the limits of human knowledge and the revelation of the constant changes in nature. If no creature died on earth, then it would be impossible to wait for some higher order to which existence is heading. People are especially aware of it. Because in this situation - the immortality of the once born life - the only goal that can be guided by nature: "revealing and maintaining reason" would be fulfilled already in the world in which we were to exist. In this way, the circle of life would be closed, and the same - without the possibility of rebirth and development - would be deprived of much greater sense. However, the phenomenon of death is a bridge, that helps the human spirit enter a new life, where nature also does not disappear, and shines with a new glow in the service of humanity. ${ }^{26}$ This perfection is rational and necessary, considering the harmony and logic of nature contained in every act of creation and dying of immortal - indeed, nature. Death is an elevated, heroic event and subordinate to a higher order; an act equally independent and just.

For Artur Schopenhauer, living in the first half of the nineteenth century (died in 1860), the end appeared as the ultimate manifestation of suffering, which distinguishes not only conscious life. It is the result of a higher drive of nature, which at the moment of birth pushes a man (in general, entire life) to the inevitable and tragic end, not taking into consideration our worldly efforts and expectations. However with "every breath" and "every second" we defend ourselves against the ubiquitous death, yet nothing can delay its arrival. "Ultimately," says A. Schopenhauer, "it must

25 J.G. Fichte, Powołanie człowieka, PWN, Warszawa 1956, p. 211.

26 Ibidem, p. 212. Fichte expressed this thought as follows: "my spiritual eye is entering a new life, which I will live by myself, and nature for me". 
be victorious, because we have been involved in it as a result of birth and only play with our prey, moments before it devours us" ${ }^{27}$ In spite of this, man, regardless of the certainty of his passing away, and the inevitable finale of the farce in which he plays the role of a condemned man, strongly engages himself in his affairs, and cares for things that do not make sense from the point of view of every existence. Therefore, the attitude and courage of many people in face of their own transience, given the knowledge of the life they have, is astounding. However, this extremely varies. While young people do not see death and sometimes even sneer at it, keeping it out of their mind, the older people - especially those who looked into death's eyes - sense the vastness of suffering that lies behind the act of passing away. The first, if not accepting their own end, naively believe that death does not concern them. Others, while waiting for the final solution equally naively believe, that there is enough time for the remaining life of their own, but not enough for others. At the root of this "well-being" lie impulses, among which the desire for existence and survival leading human deeds astray, that is, the digestion of days, months and years for trivial matters. "While we are young", said the philosopher, "it seems to us that life is endless, whatever we are told, and we deal with time accordingly. The more we age, the more economically we manage our time. For in a later age, experiencing each day, we experience a similar feeling, like a condemned man at every step, when he is lead to his death". ${ }^{28}$

In the philosophy of Ludwig Feuerbach (XIX century), the problem of the impermanence of life served to underlie human consciousness with aspirations and goals. The human self in this conception appeared as a time-limited creature, individualized and at the same time real for himself and others. Accordingly, death as a negation of individualism and reality showed both the boundaries of existence and the form of life manifestation in a given moment for each individual. The end, being also a revelation of the goal of human life, is at the same time an affirmation and negation of its durability in nature, and in the world of other people. After all, everyone dies alone and on their own. Thus, the disappearance of existence is not only a biological interruption of life, but also "coming out" of social relations, emotional relationships (death strongly influences the creation of love and its mutation, for example, regret) and the source of comparisons: individual achievements, fulfilling life roles, usefulness, etc., of the deceased, for the social environment.

"Death - wrote L. Feuerbach - has so much reality in itself, as it has through comparison and relations. Only with the assumption that the world is real, one is in the position of comparison and relational descriptions [the view of the deceased and his evaluation ], and can speak of the reality - of death or immortality. Death occurs only when it is compared to what it was - [life] earlier. and with this knowledge one

27 A. Schopenhauer, Świat jako wola i przedstawienie, PWN, Warszawa 1994, p. 474.

28 Idem, Aforyzmy o mądrości życia, Czytelnik, Warszawa 1990, p. 194. 
is alone" ${ }^{29}$ The end of the individual is the end only for those who are still alive, or for someone who is waiting for the interruption of existence (convict, soldier before the battle, incurably ill, etc.). Indeed, non-existence for the dead is indifferent, just as life is indifferent to unborn people. Thus, the disappearance of existence is not the end for the deceased - because it does not concern him (he does not realize it) - but for the observer. Death is therefore understandable and properly interpreted only by the immediate surroundings of the deceased person, not by the person himself. For this reason, absence in dead person does not exist, because it manifests itself only for people involved in worldliness.

"Death - wrote L. Feuerbach - is (...) the boundary of life, with no existence and reality; that is why life is infinite, because at its edge there is nothingness. What at the edge loses existence, ceases to be the ways it was before, same way as life ceases in death, becoming infinite (...) Since the measure of existence depends on the measure of non-being" ${ }^{30}$ Due to the fact that death is only an appearance of negation, immortality is also the affirmation of deceptive life. Therefore, there are those who claim that it does not matter how long a person stays on earth, but it is important for what reasons. Length, duration, and consequently eternity (as an abstract idea of the continuity of life) do not define the quality of existence, but only its natural dimension. The fact that one is an immortal subject does not mean anything, but what matters is the character of a person, and what values and meanings one give the others. The mortal creature in this configuration is indifferent to everyone (except for the individual concerns). After all, nothing special depends on it. That's why life can be somewhere, or it may not be at all. And so only a few will notice the loss of a marginal biography. On the other hand, the immortal person is whose life is essential and necessary, associated with "inalienable and infinite matters. "This is why being immortal - stressed Feuerbach - means being really something, since being something does away with no meaning, deleting no meaning, deletes indifference and randomness, and a the same time mortality. (...) Immortality is autotelic" ${ }^{31}$ However, this value in itself does not result from the anointing or the gift of the Creator, but from the possibilities and potencies of truly creative individuals, freed from faith (mainly Protestant) into immortality in $\operatorname{God}^{32}$, and one could add - self-righteousness.

The creator of Christian existentialism and precursor of the twentieth-century existential thought Søren Aabye Kierkegaard (19th century) recognized that the basic feature of human existence is its temporality and indifference. Durability itself can not be included in any limiting system, as rigid norms and rules that mark human

\footnotetext{
L. Feuerbach, Myśli o śmierci i nieśmiertelności, [in:] Wybór pism, t. 1, PWN, Warszawa 1988, p. 186. Ibidem, p. 190-191.

Ibidem, p. 194-195.

Ibidem, p. 197-198.
} 
thought and define our action, argue with the essence of life, which is constantly developing, is becoming different, never ending and is unpredictable. This is because there is no unity in existence, because such cohesion is only the creation of thought, not of being filled with variability and anxiety. Thought can be expressed in notches, in the system, and existence. It is possible to plan, to assume the future, while in no way to submit to human reasoning and easily succumb to the laws of nature. "Most people live - wrote S. Kierkegaard - to earn a living; if they have already earned it, they live to earn a better living, and when they have achieved it, then they die". ${ }^{33}$ "What an empty and senseless is life! - he would say elsewhere - He buries a man, goes to a funeral, throws three handfuls of earth on a coffin; he is going by a carriage, he returns with a carriage; he is consoling himself with the fact that he has a long life ahead of him. And is it a lot of $7 \times 10$ ?" $^{34}$

The worst of man's antinomies, his contradictions and suffering, come from the fact that a subject entangled in inner conflicts resulting from understanding the opposite between his changeable fate and unchanging being, transience and eternity, is unable to grasp the meaning of life without referring to the transcendence expressed by religion. It is necessary, indispensable, but at the same time full of doubt and suffering. There is too big of the gap between the Creator and man, and nothing can fill it. In life, every approach to God humiliates man and convinces him of his own powerlessness. It evokes on the one hand "fear and trembling", as a natural way that God reveals in human existence, and on the other hand, it is despair as a kind of "illness to death". The paradox of the relationship between the Absolute and man is not the result of the weakness of the human mind, but a natural expression of the relationship of the powerless being, transient, to the incomprehensible and eternal Being. However, man, especially his spirit, is a peculiar "synthesis of infinity and finitude, temporality and eternity, freedom and necessity" 35 ; it is a self based "clearly on the Force that sets it up". ${ }^{36}$ The despair attributed to human existence revealed in the fearful relationship of man to death is, therefore, a synthetic consequence of the unsuccessful combination of these contradictions in his self and "is reflected infinitively on the connection with this Power which this relationship founded".

For the last great philosopher of the XIX century, Friedrich Nietzsche, thinking about death rather contrasts it with the richness and diversity of life. Death, as the opposite of life, determines its value, measured not according to the current endeavors of temporality, or the design of a futile future, but according to the effort put into a useful and courageous life. Many die too late and some die too early. Often

\footnotetext{
3 S. Kierkegaard, Albo - albo, t. 2, PWN, Warszawa 1976, p. 381.

4 Ibidem, p. 30-31.

S. Kierkegaard, Choroba na śmierć, Wydawnictwo Zysk i S-ka, Poznań 1995, p. 15.

Ibidem, p. 16.

Ibidem.
} 
those who die too late are greedy to live, they are focused on the apparent persistence expressed in the passive experience of everyday life, without invention and the idea of a creative tomorrow. On the other hand, those who die too early can pursue it thoughtfully and fully, with a trace of a successful but short life. The existence is not about the length of existence, but about its quality and subjective and social sense. The ultimate wisdom of man manifests itself in the ability to live and die at the right time, because only success crowns death without fear. F. Nietzsche wrote: "Who never lived timely enough, why would he die on time. May he never be born. - I advise the superfluous". ${ }^{38}$ Whoever has a purpose in life and leaves his legacy, he is not afraid of death, on the contrary, he desires it. Because "the one, who desires fame, should right away say farewell, and practice the hard art of leaving life [when it's time]" ${ }^{39}$ The goodness of dying "on time", means a moment free from fear of death, and is available only to a few. Most people, however, have neither a sense nor a chance to understand what is life, and theirs ends in agony. People overwhelmed with everyday life, and the needs to satisfying, grow in the conviction that what "until now was, is nothing, but a near future is everything for everyone" ${ }^{40}$ Lack of respect for the past and excessive esteem for the future is the result of ignoring the meaning and disrespecting the presence. Only in the latter is born the fame, and achievements of a man freeing himself from fears of passing away. The moment of life, which is here and now, contradicts the point of always existing in the future. But people believe that the thought that death will not come soon, since they believe that they were born to live, not for death. The future, therefore, is the criterion of vitality and not agony, although the inevitability of this is obvious. The end of the presence in a man, does not close the past, but destroys all future. This is why people tend to postpone the thought of death, improving and not limiting their actions. Only rejecting death is the ascent to a joyful life, which creates the chance to fulfill the existence admired or wanted.

"How strange", wrote F. Nietzsche, "that this only certainty and kinship has almost no influence on these people, and that they are far from being aware of the brotherhood in death! I am happy to see that people completely think they do not want to die. I would gladly help them to think about life, what is a hundred times more worth thinking". ${ }^{41}$

38 F. Nietzsche, Tako rzecze Zaratustra, Wydawnictwo Zysk i S-ka, Poznań 1995, p. 62.

39 Ibidem.

40 F. Nietzsche, Wiedza radosna, Warszawa 1907, p. 225.

41 Ibidem, p. 226. 


\section{BIBLIOGRAPHY}

[1] Bacon F, Eseje, transl. Cz. Znamierowski, PWN, Warszawa 1959.

[2] Brodziak A., Jesteś nieśmiertelny, Zakład Poligraficzno-Papierniczy, Bytom 1990.

[3] Burckhardt J., Kultura Odrodzenia we Włoszech, transl. M. Kreczkowska, PIW, Warszawa 1991.

[4] Feuerbach L., Myśli o śmierci i nieśmiertelności, [in:] Wybór pism, t. 1, transl. K. Krzemieniowa and M. Skwieciński, PWN, Warszawa 1988.

[5] Fichte J.G., Powołanie człowieka, transl. A. Zieleńczyk, PWN, Warszawa 1956.

[6] GARIn E., Filozofia Odrodzenia we Włoszech, transl. K. Żaboklicki, PIW, Warszawa 1969.

[7] Heller M., Kwantowa kosmologia i ostateczne rozumienie wszechświata, „Problemy” 1989, nr 2.

[8] KierkegaArd S., Albo - albo, t. 2, transl. J. Iwaszkiewicz, PWN, Warszawa 1976.

[9] KierkegaArd S., Choroba na śmierć, transl. J. Iwaszkiewicz, Wydawnictwo Zysk i S-ka, Poznań 1995.

[10] Legowicz J., Zarys historii filozofii. Elementy doksografii, Wiedza Powszechna, Warszawa 1983.

[11] Montaigne M., Próby, transl. T. Żeleński (Boy), t. 1, PIW, Warszawa 1957.

[12] Nietzsche F., Tako rzecze Zaratustra, transl. W. Berent, Wydawnictwo Zysk i S-ka, Poznań 1995.

[13] Nietzsche F., Wiedza radosna, transl. L. Staff, Nakład Jakuba Mortkiewicza, Warszawa 1907.

[14] Pascal B., Myśli, transl. T. Żeleński (Boy), Instytut Wydawniczy Pax, Warszawa 1989.

[15] Pascal B., Rozprawy i listy, transl. T. Żeleński (Boy), Wydawnictwo Pax, Warszawa 1962.

[16] Schopenhauer A., Aforyzmy o mądrości życia, transl. J. Garewicz, Czytelnik, Warszawa 1990.

[17] Schopenhauer A., Świat jako wola i przedstawienie, t. 1, transl. J. Garewicz, PWN, Warszawa 1994.

[18] Sмiтн A., Teoria uczuć moralnych, transl. D. Petsch, PWN, Warszawa 1989.

[19] Spinoza B., Etyka w porządku geometrycznym dowiedziona, transl. I. Myślicki, PWN, Warszawa 1954.

[20] Tatarkiewicz W., Historia filozofii, t. 3, VI edition, PWN, Warszawa 1968.

[21] Unamuno M., O poczuciu tragiczności życia wśród ludzi i wśród narodów, transl. H. Woźniakowski, Wydawnictwo Literackie, Kraków-Wrocław 1984.

[22] Walicki M., Studia renesansowe, Ossolineum, Wrocław 1964.

[23] Wolter, O życiu, miłości i śmierci, choice \& transl. J. Adamski, PWN, Wrocław 1961.

[24] Życiński J., Filozofia w nowej fizyce, „Problemy” 1989, nr 6.

\section{WOKÓŁ BEZPIECZEŃSTWA EGZYSTENCJALNEGO, CZYLI NOWOŻYTNA RECEPCJA ŚMIERCI W FILOZOFII}

Streszczenie. Autorzy kontynuują dyskusję na temat przemijania jako egzystencjalnego problemu bezpieczeństwa w filozofii, rozumianego różnie w poszczególnych okresach historycznych. Trzeci artykuł na ten temat przedstawia współczesne stanowiska filozoficzne na temat czasowości człowieka, z przemijaniem nieustannie pojmowanym jako kryterium zagrożenia egzystencjalnego. Koniec istnienia traktowany jest jako źródło lęku, ale tym razem wolnego od wcześniejszych (tzn. średniowiecznych) inspiracji opartych na ekspiacji i nadziei na zbawienie, uważanych teraz za barierę niekwestionowanych nagród życiowych w materialistycznie wyobrażonym świecie. Współczesne koncepcje życia, które zostały uwolnione, nie bez trudności, od religijnej intelektualnej dominacji, przepowiedzianych wizji nieśmiertelnego, ale doczesnego istnienia. Stąd egzystencjalne bezpieczeństwo z tego wynikające było czasem odległe od teologii, mimo że nie kwestionowało dwuwymiarowej interpretacji bytu i popierało 
koncepcję życia wyjaśnioną przez proces naukowych (i filozoficznych) dociekań, sugerowanych przez studia w zakresie mechaniki lub medycyny. Pomimo znaczenia zmian intelektualnych, które nastąpiły po rozdzieleniu filozofii od teologii ( $w$ XVI wieku), a następnie wyodrębnieniu nauki z filozofii (w XVII wieku), pozycje związane z przemijaniem (śmierć) były raczej ograniczone w porównaniu do na przykład tych w starożytnym okresie i dość trywialnie komentowały ten ostatecznie najważniejszy epizod życiowy, biorąc pod uwagę celowość życia, jak to było widoczne w średniowieczu. Bez względu na to, waga poglądów egzystencjalnych jest ciężka w czasach współczesnych, a nawet fascynująca, na przykład w przypadku Sorena Kirkegaarda. Biorąc pod uwagę tę okoliczność świadomej wypowiedzi o lęku przed śmiercią i obecności w materialnych aspektach życia, przedstawia dość znaczące kwestie odnoszące się do umierania, jak autorzy szkicują. Z tego powodu związek między dostrzegalnym egzystencjalnym pojawieniem się życia a jego kontekstem bezpieczeństwa będzie widoczny w wyemancypowanej europejskiej nowoczesnej filozofii.

Słowa kluczowe: indywidualne bezpieczeństwo, filozofia, nowoczesność, zagrożenie, przemijalność. 